\title{
Effect of Corchorus Olitorius Extract On Haematological and Plasma Biochemical Parameters in Male Albino Rats
}

\author{
${ }^{1}$ K.O. Oyedeji And A.F. Bolarinwa ${ }^{2}$ \\ ${ }^{I}$ Department of Physiology, College of Medicine and Health Sciences, Afe Babalola University, Ado-Ekiti, \\ Nigeria. \\ ${ }^{2}$ Department of Physiology, College of Medicine, University of Ibadan, Ibadan, Nigeria.
}

\begin{abstract}
The effect of oral administration of aqueous extract of Corchorus olitorius (AECO) at doses of 250 $\mathrm{mg} / \mathrm{kg} \mathrm{BW}, 500 \mathrm{mg} / \mathrm{kg} \mathrm{BW}$ and $750 \mathrm{mg} / \mathrm{kg}$ BW on haematological and plasma biochemical parameters in male albino rats were investigated. The extract was administered on daily basis for 30 days and blood samples were collected for haematological and plasma biochemical assays.

Treatment of rats for 30 days with all the treatment doses $(250 \mathrm{mg} / \mathrm{kg} \mathrm{BW}, 500 \mathrm{mg} / \mathrm{kg} \mathrm{BW}, 750 \mathrm{mg} / \mathrm{kg}$ $B W)$ of AECO caused insignificant ( $p>0.05$ ) changes in PCV, RBC, MCV, MCHC, MCH, platelet, neutrophil, lymphocyte, eosinophil and monocyte values relative to their respective controls, but caused significant $(p<0.05)$ decrease in TWBC count relative to the control. Treatment of rats with $750 \mathrm{mg} / \mathrm{kg} \mathrm{BW}$ of AECO cause significant ( $p<0.05$ ) increase in total protein level relative to the control, but $250 \mathrm{mg} / \mathrm{kg} \mathrm{BW}$ and $500 \mathrm{mg} / \mathrm{kg} \mathrm{BW}$ of AECO caused significant $(p<0.05)$ reductions in globulin levels.

These findings suggest that aqueous extract of Corchorus olitorius could have both harmful and beneficial potentialities on the blood chemistry of male albino rats.
\end{abstract}

Key words: Corchorus olitorius, Red blood cell, Total white blood cell, Albumin, Albino rats.

\section{Introduction}

Corchorus olitorius (Tiliaceae) is an annual herb whose leaves and roots are used as herbal medicine and eaten as vegetable by local people in East Malaysia, India, Egypt, and Philippines (Zeghichi et. al., 2003). et. al., 1994).

Traditionally, its leaves are used in the treatment of pain, fever, chronic cystitis and tumors (Abu-Hadid

Its seeds have been reported to posses estrogenic activity (Sharf et. al., 1979) as well as contain high content of hydrogen cyanide and several cardiac glycosides (Negm et. al., 1980). Its extract has been reported to suppress transformation of the aryl hydrocarbon receptor induced by dioxins (Nishiumi et. al., 2005). Its polyphenolic isolate has been reported to have antiobesity effect (Wang et. al., 2011). Its aqueous extract has also been reported to have protective effect in arsenic-induced myocardial injury (Das et. al., 2010).

However, due to dearth of information from literature on the effect of Corchorus olitorius on haematological and plasma biochemical parameters in albino rats, this study therefore aims at investigating the effect of aqueous extract of Corchorus olitorius on these aforementioned parameters in male albino rats.

\section{Experimental Animals}

\section{Materials And Methods}

Adult male albino rats weighing between $160 \mathrm{~g}$ and $180 \mathrm{~g}$ bred in the Animal House of Physiology Department, LAUTECH, Ogbomoso were used. They were housed under standard laboratory conditions with a 12 hours daylight cycle and had free access to feed and water; they were acclimatized to laboratory conditions for two weeks before the commencement of the experiments. All experiments were carried out in compliance with the recommendations of Helsinki's declaration on guiding principles on care and use of animals.

\section{Plant Material}

Fresh specimens of Corchorus olitorius harvested from a local farm in Ogbomoso, Nigeria, were authenticated in the taxonomy unit of the department of pure and Applied Biology, LAUTECH, Ogbomoso.

\section{Preparation of Aqueous Extract of Corchorus olitorius (AECO)}

Large quantities $(2.00 \mathrm{~kg})$ of the fresh specimens of Corchorus olitorius were washed free of soil and debris, and the roots were separated from the leaves and stems. The leaves and stems were air-dried for four weeks, and the dried specimens were pulverized using laboratory mortar and pestle.

Weighed portion $(590 \mathrm{~g})$ of the pulverized specimens were macerated with distilled water (1:2 wt./vol.) for 72 hours at room temperature $\left(26-28^{\circ} \mathrm{C}\right)$. The resulting solution was then filtered using a wire-gauze and a 
sieve with tiny pores $(0.25 \mathrm{~mm})$. The distilled water was later evaporated using steam bath to give a percentage yield of $12.5 \%$ of the starting material.

Ten grams of the aqueous extract of Corchorus olitorius (AECO) was dissolved in $100 \mathrm{ml}$ of distilled water to give a concentration of $0.1 \mathrm{~g} / \mathrm{mL}$.

\section{Acute Toxicity Test}

Acute toxicity test was carried out as described by Turner (1971). Adult albino mice of either sex were divided into four groups with each group consisting of five animals. The mice were fasted for 18 hours with water adlibitum.

The extract was administered by gavage at doses of $2500 \mathrm{mg} / \mathrm{kg} \mathrm{BW}, 5000 \mathrm{mg} / \mathrm{kg} \mathrm{BW}$ and $7500 \mathrm{mg} / \mathrm{kg}$ BW to the first three groups. The fourth group was given $1.0 \mathrm{ml}$ of distilled water as the control group. The animals were observed for 72 hours for behavioural changes and mortality.

\section{Experimental Design}

Twenty-four animals were randomly divided into four groups with each group consisting of six rats. The four groups of rats were subjected to the following oral treatments once a day for 30 days:

Group I rats received $250 \mathrm{mg} / \mathrm{kg}$ BW of AECO

Group II rats received $500 \mathrm{mg} / \mathrm{kg}$ BW of AECO

Group III rats receive $750 \mathrm{mg} / \mathrm{kg}$ BW of AECO

Group IV rats received $0.5 \mathrm{ml}$ of distilled water as the control group.

Twenty-four hours (day 31) after the last dosing of the four groups, blood samples were collected.

\section{Collection of Blood Sample}

Blood samples were collected through the medial cantus into EDTA bottles for haematological and plasma biochemical studies. Before assays, the blood samples were centrifuge for 5 minutes using a bench-top centrifuge (Centromix) and the supernant plasma was then used for the determinations of the biochemical parameters.

\section{Determination of Haematological Parameters}

The red blood cells (RBC) and white blood cells (WBC) counts were determined by the improved Neubauer haemocytometer method. The haemoglobin ( $\mathrm{Hb})$ concentration was determined according to Jain (1986), using the cyanomethaemoglobin method. The packed cell volume (PCV) was determined by the microhaematocrit method according to Dacie and Lewis (1991). Schilling method of differential lecukocyte count was used to determine the distribution of the various white blood cells (Mitruka and Rawnsley, 1977). Mean corpuscular volume $(\mathrm{MCV})$, mean corpuscular haemoglobin $(\mathrm{MCH})$ and mean corpuscular haemoglobin concentration (MCHC) were computed according to Jain (1986).

\section{Determination of Plasma Biochemical Parameters}

The total protein concentration was determined using the Bivret method (Reinhold, 1953) and the albumin concentration by the method of Doumas et al. (1971). The globulin concentration was calculated by subtracting the albumin concentration from the total protein concentration. Activities of plasma alanine transaminase (ALT) and aspartate transaminase (AST) were determined according to the method of Duncan (1994). The level of cratinine was determined using the method of Tietz et al. (1994). All the above biochemical parameter were determined in the plasma using the Randox kits.

\section{Statistical Analysis}

The mean and standard error of mean (S.E.M.) were calculated for all values. Comparison between the control and experimental groups was done using one-way analysis of variance (ANOVA) with Duncan's Multiple Range Test. Differences were considered statistically significant at $\mathrm{p}<0.05$.

\section{Results}

The effect of AECO at various doses on the haematological and plasma biochemical parameters of albino rats after treatment for 30 days are shown in Tables 1 and 2 respectively.

Treatment of rats with all the treatment doses of AECO $(250 \mathrm{mg} / \mathrm{kg} \mathrm{BW}, 500 \mathrm{mg} / \mathrm{kg} \mathrm{BW}, 750 \mathrm{mg} / \mathrm{kg}$ BW) caused insignificant $(\mathrm{p}>0.05)$ changes in PCV, RBC, MCV, MCHC, MCH, platelet, neutrophil, lymphocyte, eosinophil and monocyte values relative to their respective controls. Treatment of rats with 750 $\mathrm{mg} / \mathrm{kg} \mathrm{BW}$ of AECO caused significant $(\mathrm{p}<0.05)$ increase in $\mathrm{Hb}$ and monocyte values. Treatment of rats with all the treatment doses of AECO caused significant $(p<0.05)$ decrease in TWBC count. 
Treatment of rats with $750 \mathrm{mg} / \mathrm{kg}$ BW of AECO caused significant $(\mathrm{p}<0.05)$ increase in total protein level relative to the control, but $250 \mathrm{mg} / \mathrm{kg}$ BW and $500 \mathrm{mg} / \mathrm{kg} \mathrm{BW}$ of AECO caused significant $(\mathrm{p}<0.05$ ) reductions in globulin levels. Treatment of rats with all the treatment doses of AECO caused insignificant ( $>>0.05)$ changes in the activities of AST and ALT as well as albumin value.

Table 1: Effect of aqueous extract on Corchorus olitorius (AECO) on haematological parameters $\left(\mathrm{n}=6,{ }^{*} \mathbf{p}<0.05\right)$

\begin{tabular}{lllll}
\hline Parameters & Control & $250 \mathrm{mg} / \mathrm{kg}$ AECO & $500 \mathrm{mg} / \mathrm{kg}$ AECO & $750 \mathrm{mg} / \mathrm{kg}$ AECO \\
\hline $\mathrm{PCV}(\%)$ & 40.00 & 40.20 & 38.40 & 42.00 \\
$\mathrm{Hb}(\mathrm{g} / \mathrm{dl})$ & 12.40 & 12.78 & 11.80 & $13.32^{*}$ \\
$\mathrm{RBC}\left(\mathrm{X} 10^{6} \mu \mathrm{L}\right)$ & 6.15 & 6.13 & 6.07 & 6.58 \\
$\mathrm{MCV}(\mathrm{FL})$ & 65.40 & 65.91 & 64.33 & 64.21 \\
$\mathrm{MCHC}(\mathrm{g} / \mathrm{dl})$ & 31.00 & 31.78 & 30.81 & 31.71 \\
$\mathrm{MCH}(\mathrm{Pg})$ & 20.29 & 20.96 & 19.85 & 20.38 \\
$\mathrm{TWBC}\left(10^{3} \mu / \mathrm{L}\right)$ & 16.46 & $9.75^{*}$ & $10.95^{*}$ & $8.62^{*}$ \\
Platelet $\left(10^{5} / \mu \mathrm{L}\right)$ & 1.35 & 1.52 & 1.62 & 2.62 \\
Neutrophil $(\%)$ & 35.20 & 44.80 & 35.20 & 39.00 \\
Lymphocyte (\%) & 62.80 & 51.80 & 60.00 & 55.60 \\
Eosinophil (\%) & 1.40 & 1.80 & 2.20 & 1.60 \\
Monocyte (\%) & 1.80 & 1.80 & 2.60 & $3.40^{*}$ \\
\hline
\end{tabular}

Table 2: Effect of aqueous extract of Corchorus olitorius (AECO) on plasma biochemical parameters

\begin{tabular}{lllll}
\multicolumn{5}{c}{$(\mathbf{n = 6 ,}, \mathbf{p}<\mathbf{0 . 0 5})$} \\
\hline Parameters & Control & $250 \mathrm{mg} / \mathrm{kg}$ AECO & $500 \mathrm{mg} / \mathrm{kg}$ AECO & $750 \mathrm{mg} / \mathrm{kg}$ AECO \\
\hline Total protein $(\mathrm{gm} \%)$ & 6.04 & 4.76 & 4.88 & $6.08^{*}$ \\
Albumin $(\mathrm{gm} \%)$ & 3.22 & 3.20 & 3.52 & 3.40 \\
Globulin $(\mathrm{gm} \%)$ & 2.82 & $1.44^{*}$ & $1.24^{*}$ & 2.68 \\
AST $(\mu / \mathrm{L})$ & 42.20 & 41.60 & 42.40 & 41.80 \\
ALT $(\mu / \mathrm{L})$ & 30.00 & 29.00 & 30.40 & 27.60 \\
\hline
\end{tabular}

\section{Discussion}

The $\mathrm{LD}_{50}$ gives a measure of the immediate or acute toxicity of a test substance (Lorke, 1983). This study revealed that AECO at high doses of $2500 \mathrm{mg} / \mathrm{kg} \mathrm{BW}, 500 \mathrm{mg} / \mathrm{kg} \mathrm{BW}$ and $7500 \mathrm{mg} / \mathrm{kg} \mathrm{BW}$ had no apparent toxic and lethal effects on the animals which probably indicates that the extract has high safety index. This could be due to hepatic metabolism of the toxic potentialities of the extract, since the extract is administered orally.

The values obtained for RBC showed the non-significant effects of 30-day treatment of rats with $\mathrm{AECO}$ on red blood cells (RBC) counts and indices relating to it (PCV, MCV, MCH and MCHC) when compared with the control. This is an indication that there was no destruction of red blood cells and no change in the rate of production of RBC (erythropoiesis). This also shows that AECO does not has the potential to stimulate erythropoietin release from the kidneys, which is the humoral regulator of RBC production (Polenakovic and Sikole, 1996). The non-significant effects of the treatment of rats with AECO at all doses also indicate that there were no change in the oxygen-carrying capacity of the blood and the amount of oxygen delivered to the tissues since RBC is very important in transferring respiratory gases (De Gruchy, 1976). It has been reported that values of RBC and associated parameters lower than normal ranges are indicative of anemic conditions while higher values are suggestive of polycythemia (American Diabetes Association, 2000), thus, the treatment of rats with AECO may not have the potential to induce anemia or polycythemia. Also, the treatment of rats with AECO at all treatment doses may not have adverse effects on the bone marrow, kidney and haemoglobin metabolism, since it has been reported that only substances which significantly affect the values of red blood cells and associated parameters would have effects on the bone marrow, kidney and haemoglobin metabolism (Young and Maciejewski, 1997).

The significant reduction in TWBC count caused by AECO suggests that the immune system has been compromised. Contrary report was given by Adewusi and Afolayan (2009) in Pelargonium reniforme extract treated rats. 
The extract caused non - significant changes in the MCV and MCH values which could be an indication of absence of macrocytic anaemia since increased MCV an $\mathrm{MCH}$ values are known to be indicative of macrocytic anaemia. Also, AECO caused non- significant change in the MCHC value which suggest and absence of hereditary spherocytosis since MCHC values are known to be elevated in hereditary spherocytosis.

The insignificant change in neutrophil count caused by extract probably indicates that the ability of the body to attack and destroy invading bacteria, viruses and other injurious agents (Phagocytosis) has not been compromised. The non-significant change in lymphocyte count suggests that the acquired immune responses of the body has not been compromised by the extract; while the significant increase in monocyte count probably indicates that the phagocytic function of the body has been enhanced by the extract. The non - significant change in eosinophil count probably indicates that the anti-allergic and anti-parasitic infectious response of the body have not been compromised by extract.

Also, the insignificant change in the platelet count caused by extract could be an indication that it does not has the potential to stimulate thrombopoietin production ( $\mathrm{Li}$ et al., 1999) with the hemostatic capability of the blood maintaining the status quo since platelets mediate in the blood-clotting mechanism.

AECO at high doses caused significant increase in total protein levels, which probably indicates that the buffering capacity of the blood and body fluid balance have been enhanced. Similar report was given by Adewusi and Afolayan (2009) in Pelargonium reniforme extract treated rats. At lower doses the extract caused significant reductions in globulin levels which could indicate a compromise in both the natural and acquired immunity of the body against invading organisms. The extract caused insignificant change in albumin level which suggests the maintenance of status quo in plasma level of metals, ions, fatty acids, amino acids, bilirubin and enzymes. Contrary report was given by Adedapo et. al., (2007) in rats treated with P. amarus and $C$. anontifolius extracts. The extract caused insignificant change in the activity of ALT which probably indicates that the hepato-protective potential of the extract has not been compromised. The extract also caused nonsignificant change in the activity of AST which could indicate absence of tissue necrosis induction by the extract.

In conclusion, this study has shown that aqueous extract of Corchorus olitorius could have some toxic and beneficial potentialities on the blood chemistry of albino rats. However, its effect on human blood chemistry is unknown, nevertheless considering these findings in animal model, it is recommended that caution should be exercised in the consumption of Corchorus olitorius especially by people with blood disorder.

\section{References}

[1] Abu- Hadid AF, El-Shinawy MZ, El-Bethagy AS, Gaafer SA, Medany M (1994): Studies on the production of off-season Jew's mallow (Molokhia) in Egypt. Egypt J. Hort., 21:187-193.

[2] Adedapo A.A, Abatan MO, Olorunsogo O.O (2007): Effects of some plants of the spurge family on haematological and biochemical parameters in rats. VETERINARSKI ARHIV 77 (1), 29 - 38.

[3] Adewusi EA, Afolayan AJ (2009): Safety evaluation of the extract from the roots of Pelargonium reniforme Curtis in male wistar rats. Afr. J. Pharm and Pharmacology, vol. 3(8): pp. $368-373$.

[4] American Diabetes Association (2000): Nutrition recommendation and principles for people with diabetes mellitus clinical practice recommendations Diabetes care 23:543-6.

[5] Dacie JV, Lewis SM (1991): Practical haematology, 7th edition ELBS with Churchill Livingston, England, pp $37-85$.

[6] Das AK, Sahu R, Dua TK, Baq S et. al. (2010): Arsenic-induced myocardial injury: protective role of Corchorus olitorius leaves. Food Chem Toxicol 48 (5): 1210-7.

[7] De Gruchy GC (1976): Clinical haematology in Medical Practice. Blackwell Scientific Publication. Oxford, London pp. 33 -57.

[8] Doumas BT, Watson W, Biggs HC (1971): Albumin standards and the measurement of serum albumin with bromocresol green. Clinica Chimica Acta 31, 87-96.

[9] Duncan JR, Praise KW, Mahaffey EA (1994): Veterinary Laboratory Medicine (Clinical Pathology) 3rd ed. Iowa State University Press, U.S.A.

[10] Jain NC (1986): Schalm's Veterinary Haematology 4th ed. Lea and Fabiger, Philadelphia.

[11] Li Y, Xia, Kuter DJ (1999): Interaction of thrombopoietin with the platelet complements receptor in plasma: binding, internalization, stability and pharmacokinetics. Brit J. Haematol 106: 345.

[12] Mitruka BM, Rawnsley H (1977): Clinical, biochemical and haematological references values in normal experimental animals. Masson Publishing USA Inc. Pp. 53-54.

[13] Nishiumi S, Yabushita Y, Fukuda I, Mukai R, Yoshida K, Ashida H (2005): Molokhia (Corchorus olitorius L) extract suppresses transformation of the aryl hydrocarbon receptor induced by dioxins. Food Chem Toxicol; 44 (2): 250-60.

[14] Polenakovic M, Sikole A (1996): Is erythropoietin a survival factor for red blood cells? J. Am. Soc Nephrol 7(8): 1178-1182.

[15] Reinhold JG (1953): Manual determination of serum total protein, albumin and globulin fractions by the Biuret method Standard Methods of Clinical Chemistry (Academic Press, New York).

[16] Sharaf A, Kamel SH, Salama A, Arbid MS (1979): Oestrogenicity of Corchorus olitorius seed oil. Egypt J. Vet Med., 14:87-93.

[17] Wang L, Yamasaki M, Katsube T, Sun X, Yamasaki Y, Shiwaku K (2011): Antiobesity effect of polyphenolic compounds from molokheiya (Corchorus olitorius L) leaves in LDL receptor-deficient mice. Eur J Nutr 50:127-133.

[18] Young NS, Maciejewski J (1997): The path physiology of acquired aplastic anemia. New Eng. J. Med., 336:1365.

[19] Zeghichi S., Kallithkara S, Simopoulus AP (2003): Nutritional composition of Molokhia (Corchorus olitorius) and Stammagathi (Cichorium spinosum) in plants, in human health and nutritional policy. Simopoulus, A. P and C. Gopalan (Eds.) Karger, Basel, pp: $1-21$. 